\title{
最近の歯学
}

\section{8. 医用研無機材料}

合成アパタイトとカドミウムイオンの吸着ならびに置換反応

医用研, 無機材料 青木 秀希 加藤 一男

鉛やカドミウムなどの重金属化合物が生体に取り入れ られると，歯や骨などの硬組織に取り込まれることは周 知の事実である。またカドミウムは富山県神通川流域の イタイ・イタイ病の原因となるものとして大きな社会問 題となり衆目の認めるところである。重金属イオンが硬 組織に取り込まれる機構を究明するためには，硬組織を 構成している二大物質であるハイドロキシアパタイトと コラーゲンを分けて, 各々と, 反応機構を考える必要が ある。

筆者らは湿式法ならびに乾式法を用いて，物理化学的 諸性質の 異なるハイドロキシアパタイトを合成してき た。そこでカドミウムイオンが硬組織アパタイトといか なる反応を示すかを解明する目的で，まず合成アパタイ トとカドミウムイオンとの反応を実験的に行った結果, 興味ある 2,3 の知見を得たので以下にその大略を述べ る。

99.999\%の金属カドミウムを濃硝酸でじょじょに溶解 して, 溶解後蒸溜水で稀釈し, $\mathrm{pH}$ 中性付近の約 1,000 ppm のカドミウムイオン濃度の水溶液を調製した。こ れを, $37^{\circ} \mathrm{C}$ の恒温水槽中に放置した。この反応液にカ ドミウムイオン電極を投入し，あらかじめ標準液で調整 してあるイオンメータに直結し, 溶液中のカドミウムイ オン濃度変化を直接, 連続的に測定できるようにした。 温度やメータが定常状態になったときに，合成した結晶 質ならびに非晶質ハイドロキシアパタイトを一定量投入 して反応を行なった。比較としてアパタイトの他に活性 炭, 活性ゼオライトさらに仮焼牛骨も使用した。また, 一定時間ごとに反応液を採取し，反応主成物を粉末 X線 回折法で同定した。

一定濃度のカドミウムイオンを含む反応液 11 中に試 料各 $1 \mathrm{~g}$ を投入して約20時間反応を行い，溶液中のカド ミウムイオン濃度変化を右図に示した。反応開始から 1 分以内の短時間で，活性炭，仮焼牛骨を除いて各試料と も急激な濃度减少が認められた。長時間になると合成ア パタイトが最を多くカドミウムイオンを取り込むことが わかった。 2 種類のアパタイトでは, 反応初期には非晶

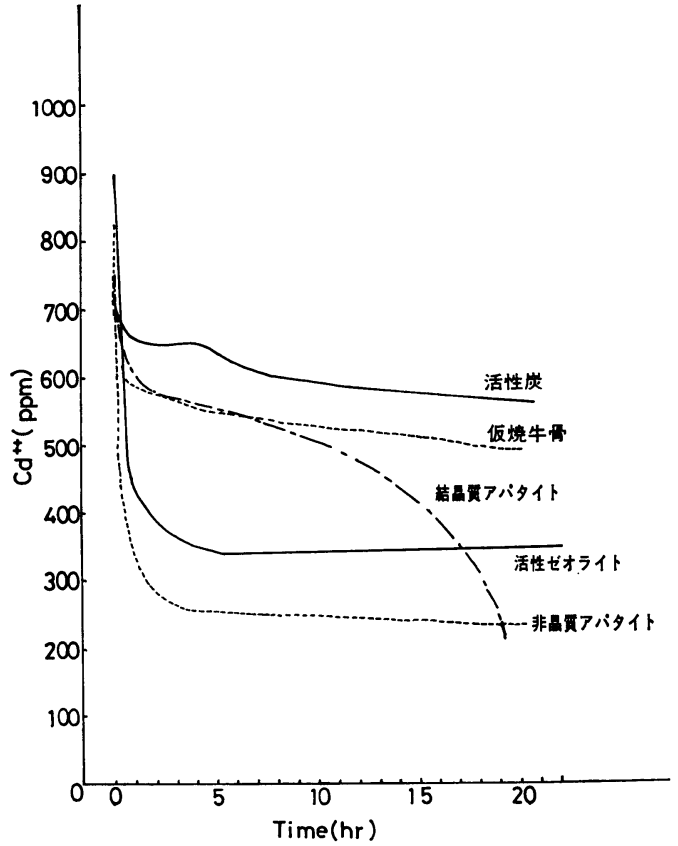

質アパタイトがより多くカドミウムイオンを吸収する が，反応後期になると同ていどとなる。仮焼牛骨は反応 開始後ほぼ一定に減少するが合成アパタイトほどカドミ ウムイオンを取り込まない。活性炭はカドミウムイオン に対して，ほとんど吸着能がないと考えられた。反応生 成物をX線回折法で調べると, 合成アパタイトは, 反応 1 時間以内では主に吸着反応で，1 時間以後ではじょじ ょに置換反応を起こし，最終的には全く別のリン酸水素 カドミウム $\mathrm{Cd}_{5} \mathrm{H}_{2}\left(\mathrm{PO}_{4}\right)_{4} \cdot 4 \mathrm{H}_{2} \mathrm{O}$ が生成することがわ かった。仮焼牛骨は反応 20 時間ていどではほとんど置換 反応を起こさないこともわかった。しかし，仮焼して結 晶が大きくなった仮焼牛骨ではなく, 生の骨や歯では置 換反応も考えられる。なお本大学・歯学部生化学教室に おいて，硬組織中のコラーゲンとカドミウムイオンとの 反応について検討されており，筆者らもより詳細な考察 も現在行っている。 